\title{
EFFECT OF COCARBOXYLASE ON THE DEVELOPMENT OF GALACTOSE CATARACT IN RATS*
}

\author{
BY
}

\author{
R. VAN HEYNINGEN, A. PIRIE, AND J. BLACKWELL \\ Nuffield Laboratory of Ophthalmology, University of Oxford
}

HöRMANN (1954) reported that regular subcutaneous injections of cocarboxylase (vitamin $B_{1}$ pyrophosphate) prevented the development of galactose cataract in young rats. He fed 70 per cent. of the diet as lactose or 30 per cent. as galactose. The diet of 70 per cent. lactose was toxic and the rats died before cataract occurred, although histologically early lens changes were detectable. Three litters of rats were fed 30 per cent. galactose and in two of them all the rats had complete lens opacities in 45-58 days. In the third litter, which was from one of the rats showing galactose cataract, the lens opacities were less severe.

Five rats fed 30 per cent. galactose and given injections of cocarboxylase showed minimal lens changes that disappeared when the dose of cocarboxylase was increased; five rats fed 70 per cent. lactose, and also given cocarboxylase not only showed no cataract but also survived for the 100 days of the experiment, in contrast to the rats fed 70 per cent. lactose, without cocarboxylase which died within 12-14 days.

Cocarboxylase is a coenzyme for the oxidation of pyruvic acid by animal tissues, and is therefore a vital link in the chain of reactions through which glucose is oxidized. Hörmann's results appeared so interesting and important that we undertook a small scale repetition of his experiment, but unfortunately we have been unable to confirm his results.

\section{Methods}

Apart from three modifications which will be described, we followed Hörmann's technique and diet exactly. Weanling albino rats (33-50 g.) were used. These were housed in individual cages on wire mesh screens.

Diet

30 per cent. galactose

15 per cent. casein (fat and vitamin free)

40 per cent. oatmeal

9 per cent. olive oil

2 per cent. liver oil

4 per cent. salt mixture

Water ad lib.

* Received for publication September 23, 1954. 
Each rat also received $0.5 \mathrm{~g}$. dried yeast and 5 drops liver oil daily.

Cocarboxylase.-Berolase $\dagger$ was used.

Modifications of Hörmann's Technique

(1) Instead of comparing one litter with another we made up two groups of six rats, three from each of two litters. The groups were as equal as possible as regards sex and initial weight.

(2) The rats were fed by the paired feeding method. Group I was at first given the diet plus subcutaneous injections of $5 \mathrm{mg}$. cocarboxylase every fourth day. The dose was later increased to $10 \mathrm{mg}$. every fourth day, according to Hörmann's procedure. Group II was given the diet alone, each rat receiving only as much food as its opposite number in Group I had eaten the previous day.

In this way we hoped to eliminate differences due to litter, sex, and appetite. The rats grew well (2-3 g./day) in both groups.

(3) After the first few days it was discovered that the oatmeal (porridge oats, coarse ground) was being picked out from the diet by most of the rats, while a few were discarding the oatmeal in favour of the rest of the diet. A more finely ground preparation of oatmeal (medium ground) was therefore substituted on the sixth day and used for the rest of the experiment. The rats were unable to pick out their favourite food from the resulting mixture and it was thus assured that galactose formed $\mathbf{3 0}$ per cent. of the food eaten. In Hörmann's experiment the fact that "haferflocken" (oatflakes) was used makes it reasonably certain that this condition was not fulfilled and that the rats were able to discriminate between oatflakes and the rest of the diet. This, together with the fact that the rats were not pair fed, makes it likely that the absolute and relative amounts of galactose in the food eaten varied considerably from day to day and from rat to rat.

Estimation of Galactose and Glucose.-Galactose plus glucose was estimated by the method of Nelson (1944), and galactose alone by the same method after glucose had been removed by fermentation with yeast.

\section{Results}

Lens changes were examined by the slit lamp, and sometimes the ophthalmoscope and loupe, after dilatation of the pupil with 0.2 per cent. atropine. The eyes were examined every 2 to 3 days at first and later about every 5 days.

All the rats showed lens changes at the equator 10 or 12 days after the start of the experiment. No changes were visible at 7 days and there was no difference between the two groups.

The opacities developed quite rapidly and followed the usual pattern (Bellows, 1944). The first complete opacities (dense white lens) appeared after 30 days and all except one of the rats had opaque lenses by the 73rd day. In four pairs the cocarboxylase-treated rat developed opaque lenses later than the untreated control; in one pair there was no difference, and in one pair the lens of the treated rat became opaque first. There was no sex difference in the onset of opacity. The results are set out in Table I (opposite). 
TABLE I

TIME OF DEVELOPMENT OF GALACTOSE CATARACT

\begin{tabular}{|c|c|c|c|}
\hline \multirow{2}{*}{ Rat No. } & \multicolumn{2}{|c|}{ Days on diet } & \multirow{2}{*}{$\begin{array}{l}\text { Difference between Time of } \\
\text { Complete Opacity in Cocarb- } \\
\text { oxylase-treated rats and in } \\
\text { Controls (days) }\end{array}$} \\
\hline & $\begin{array}{l}\text { First Change seen } \\
\text { in Lens }\end{array}$ & $\begin{array}{l}\text { Lens Opaque to } \\
\text { Naked Eye }\end{array}$ & \\
\hline $\begin{array}{l}1 \\
7\end{array}$ & $\begin{array}{l}10 \\
10\end{array}$ & $\begin{array}{l}59 \\
30\end{array}$ & +29 \\
\hline $\begin{array}{l}2 \\
8\end{array}$ & $\begin{array}{l}10 \\
10\end{array}$ & $\begin{array}{l}59 \\
38\end{array}$ & +21 \\
\hline $\begin{array}{l}3 \\
9\end{array}$ & $\begin{array}{l}12 \\
10\end{array}$ & $\begin{array}{c}\text { not completely opaque } \\
52\end{array}$ & $<+24$ \\
\hline $\begin{array}{r}4 \\
10\end{array}$ & $\begin{array}{l}12 \\
10\end{array}$ & $\begin{array}{l}69+ \\
73+\end{array}$ & - \\
\hline $\begin{array}{r}5 \\
11\end{array}$ & $\begin{array}{l}10 \\
10\end{array}$ & $\begin{array}{l}52 \\
59\end{array}$ & -7 \\
\hline $\begin{array}{r}6 \\
12\end{array}$ & $\begin{array}{l}12 \\
10\end{array}$ & $\begin{array}{l}52 \\
38\end{array}$ & +14 \\
\hline
\end{tabular}

+ One lens opaque, the other very bad.

Rats No. 1-6 were injected with cocarboxylase. Rats No. 7-12 were pair-fed controls.

The delay in reaching full cataract visible to the naked eye in four of the six cocarboxylase-treated rats does not seem significant, since the lenses of all of them were very abnormal with large vacuoles in the anterior cortex and with posterior opacities. In this experiment therefore cocarboxylase did not, in our view, exert any appreciable influence on the initial appearance of galactose cataract or on the course of opacity formation.

Galactose in the Lens.-There is very little information about galactose in

TABLE II

\section{PENETRATION OF GALACTOSE INTO CALF LENS IN VITRO}

\begin{tabular}{c|c}
\hline $\begin{array}{c}\text { Time of Incubation } \\
\text { (hrs) }\end{array}$ & $\begin{array}{c}\text { Lens Galactose } \\
\text { (mg./100 g. wet wt) }\end{array}$ \\
\hline 0 & 0 \\
1 & $9 \cdot 6$ \\
2 & 20.8 \\
3 & 24.9 \\
$3 \cdot 5$ & $51 \cdot 0$ \\
4 & 30.7 \\
4.5 & 42.4 \\
5.5 & 33.1 \\
\hline
\end{tabular}

Calf lenses (weight approx. $1 \mathrm{~g}$.) were incubated at $37^{\circ} \mathrm{C}$. in open tubes in 10-ml. Krebs ringer phosphate containing $100 \mathrm{mg}$. per cent. glucose and $210 \mathrm{mg}$. per cent. galactose. They were removed after different time intervals and analysed for galactose. the lenses of galactose-fed rats, though it is well known that their blood and aqueous humour contain a high concentration of galactose. Sasaki(1938) measured the total reducing sugar (glucose plus galactose) and deduced that galactose probably did not enter the rat lens in vivo. Ross (1953) showed that galactose did not enter the decapsulated rabbit lens in vitro. We have found that galactose does to some extent penetrate the intact calf lens in vitro. Table II shows that after the first few hours, the penetration 
from a fluid containing $210 \mathrm{mg}$. galactose $/ 100 \mathrm{ml}$. stopped at about $30-50 \mathrm{mg}$. galactose $/ 100 \mathrm{~g}$. lens.

The few figures we were able to obtain on the galactose and glucose concentration in the severely cataractous lens of galactose-fed rats are given in Table III. There was not sufficient material for duplicate determinations. The most we can say is that some galactose penetrated into rat lenses made cataractous by feeding galactose, but that it did not reach a high concentration.

TABLE III

GALACTOSE AND GLUCOSEIN CATARACTOUS LENSES OF GALACTOSE-FED RATS

\begin{tabular}{|c|c|c|c|c|c|}
\hline \multicolumn{2}{|c|}{ Pooled Lenses } & \multicolumn{2}{|c|}{ Lens (mg./100g. wet wt.) } & \multicolumn{2}{|c|}{$\begin{array}{l}\text { Aqueous Humour } \\
\text { (mg./100 ml.) }\end{array}$} \\
\hline No. of Rats & Group* & Glucose & Galactose & Glucose & Galactose \\
\hline 4 & $\mathbf{I}$ & 59 & 79 & 111 & 115 \\
\hline 2 & I & - & 31 & - & - \\
\hline 4 & II & 31 & 31 & - & - \\
\hline 1 & II & - & 35 & - & - \\
\hline
\end{tabular}

\section{Summary}

The finding that regular subcutaneous injections of cocarboxylase prevented the development of galactose cataract in young rats (Hörmann, 1954) has not been confirmed.

Galactose penetrates to some extent into the normal calf lens in vitro and into the cataractous rat lens in vivo.

We wish to thank Roche Products Ltd. for a gift of cocarboxylase.

\section{REFERENCES}

Bellows, J. G. (1944). " Cataract and Anomalies of the Lens". Kimpton, London. Hörmann, E. (1954). v. Graefes Arch. Ophthal., 154, 561.

Netson, N. (1944). J. biol. Chem., 153, 375.

Ross, E. J. (1953). Nature (Lond.), 171, 125.

SASAKI, T. (1938). v. Graefes Arch. Ophthal., 138, 365. 